\title{
Detection of Non-Alcoholic Beer Spoilage Microorganisms at Critical Points of Production by Polymerase Chain Reaction
}

\author{
Fatemeh Zendeboodi ${ }^{1}$ (D) , Behrooz Jannat ${ }^{2}$, Sara Sohrabvandi ${ }^{2,3 *}$ (D) , Elham Khanniri ${ }^{1}$, Amir Mohammad \\ Mortazavian $4^{(1 D}$, Kianoush Khosravi ${ }^{3}(\mathbb{D})$, Mohammad Mahdi Gholian ${ }^{5}$ (D), Bahareh Sarmadi ${ }^{*}$, Nasrin \\ Haji Seyed Javadi ${ }^{3}$
}

1 Student Research Committee, Department of Food Science and Technology, Faculty of Nutrition Sciences and Food Technology, National Nutrition and Food Technology Research Institute, Shahid Beheshti University of Medical Sciences, P.O. Box 19395-4741, Tehran ; fzendeboodi@gmail.com (F.Z.); e.khanniri@sbmu.ac.ir (E.K.); m.eivani@yahoo.com (B.S.);

$2 \quad$ Halal Research Center of IRI, FDA, Tehran, Iran; head-center@halal.gov.ir (B.J.);

3 Department of Food Technology Research, Faculty of Nutrition Sciences and Food Technology/National Nutrition and Food Technology Research Institute, Shahid Beheshti University of Medical Sciences, Tehran, Iran; sohrabv@sbmu.ac.ir (S.S.); kiankh@yahoo.com (K.K.); drnhsjavadi@yahoo.com (N.H.S.J.);

4 Department of Food Science and Technology, Faculty of Nutrition Sciences, National Nutrition and Food Technology Research Institute, Food Science and Technology, Shahid Beheshti University of Medical Sciences; mortazvn@ sbmu.ac.ir (A.M.M.);

5 Grape Processing and Preservation Department, Research Institute for Grapes and Raisin (RIGR), Malayer University, Malayer, Iran; mohammadmahdi.gholian@stu.malayeru.ac.ir (M.M.G.);

* Correspondence: sohrabv@sbmu.ac.ir (S.S.); m.eivani@yahoo.com (B.S.);

Received: 23.08.2020; Revised: 12.09.2020; Accepted: 14.09.2020; Published: 15.09.2020

\begin{abstract}
Detection of non-alcoholic beer contaminants is complicated as lengthy incubation time is required for cultivation; indeed, this is a need for rapid detection methods. A recent study was conducted to determine the microbiological quality of non-alcoholic beers of four brads (A-D) in Tehran, Iran. Polymerase chain reaction (PCR) is applied as a rapid and specific method for the detection of contaminants in beer manufacturing. The PCR protocols were effective for the detection of yeasts in beers during processing until packaging. The presence of wild yeasts and molds during processing could be risky and will affect the final product quality. The predominant contaminants of non-alcoholic beer were found to be the species of Saccharomyces, Pichia, Rhodotorula, Alternaria, Hansenia, Wickerhamomyces, and Cladosporium. It is essential to inform the producers about hazards, and critical control points in non-alcoholic beer processing stages, including; wort boiling, clarification, filtration, and packaging, and the implication of environmental hygiene are deniable.
\end{abstract}

Keywords: Non-alcoholic beer; Polymerase chain reaction; Critical control point; Microbial contamination; Pasteurization, Spoilage microorganisms.

\footnotetext{
(C) 2020 by the authors. This article is an open-access article distributed under the terms and conditions of the Creative Commons Attribution (CC BY) license (https://creativecommons.org/licenses/by/4.0/).
}

\section{Introduction}

Non-alcoholic beer is produced and widely consumed by people in the Islamic regions of the world [1,2]. This valuable drink is used as a refreshing, thirst-quenching, vital, and appetizer food component in these countries. Iran is one of the producers of this product in the world [3- 5]. Non-alcoholic beer is produced from a controlled and non-fermentation of barley 
malts in Iran. Major components used for producing this kind of beer includes water, malts, sugar, and flavoring agents $[6,7]$. Widely consumption of this kind of beverage causes many concerns about its microbial quality and sanitary production in Iran. Natural components of beer are one of the main sources of microbial contamination in the beer. The presence of molds (Aspergillus and Fusarium species) in barley may negatively affect the quality of malt and the beer produced from it. Equipment another factor that may affect the microbial contamination of the beer during processing when sanitation rules are not followed well during brewing [8, 9]. Beer contamination also contributes to the inadequate pasteurization stage of non-alcoholic beer [10-12]. Moreover, if pasteurization has been done before the packaging stage, container material is another impressive factor that may transfer annoying germs into the pasteurized beer [13].

To develop a better understanding of contamination related to non-alcoholic beer production, applying hazard analysis critical control point (HACCP) strategy became important. HACCP strategy defines hazards related to each stage of primitive ingredients, processing, and handling. This method monitors the relative risks in the production chain and determines effective control measurement points in each stage [14-16]. Traditionally, fungal contamination is detected using various methods, including a) observing colony morphology, b) the ability of an organism to survive in different temperatures, c) flocculation tests, and d) oxygen demands. These methods are time-consuming and do not discriminate between a variety of fungi, precisely [17]. Hence, there is a need for a rapid and accurate detecting method to monitor the quality of non-alcoholic beers.

Polymerase chain reaction (PCR) is one of the DNA-based tools which is recognized as a rapid and sensitive technique that could be applied as a diagnostic method for food product contaminants [18]. PCR has also proved to be a promising method for the rapid and sensitive detection of contaminations in the brewing industry. Most of the researches refers to the application of PCR in diagnosing lactobacilli and yeasts in beers. Therefore, specific primers of microbial species have been designed for the most prevalent beer spoiling microorganisms. Specified primers are used for the amplification of small segments of a microorganism genome. PCR technology has different advantages beyond the traditional methods include precise identification of a pure single colony base on its fingerprints in less than $24 \mathrm{~h}$ and identification of microorganisms base on genotype rather than phenotypic properties [19]. In addition, this easy and rapid technology is applicable in any location of the brewing process where pure colony detection is obtained by traditional culturing methods.

In the recent study, the hazards of brewing, which are versus to safety consumption of non-alcoholic beer, are assessed, and the critical control points (CCP) are determined. Moreover, four specific primers on the 16s rDNA gene were applied for the amplification of specified genomes and fungi present in beers.

\section{Materials and Methods}

\subsection{Selection of beer brands.}

Evaluation of hazards in Iranian non-alcoholic beer was done by a survey study of four famous brands (A, B, C, and D) samples, which were packed in Polyethylene terephthalate (PET), glass bottle $(\mathrm{G})$, and aluminum can $(\mathrm{C})$. This research was recorded in a close relationship with four beer producers in Tehran province. All brands used malt or its extract, tapped or reverse osmosis water, and some additives (sugar, flavoring agents) as materials for 
brewing. Brands A and B packed a beer in the glass bottles and PET packaging materials. Brands $\mathrm{C}$ and D packed the final product in PET and aluminum cans, respectively. The methods of preparation of beers in each company were similar in general but different in detail, for instance, brand $\mathrm{D}$ packed beers in sterilized packaging materials after the pasteurization process.

\subsection{Hazard analysis.}

Assessing the hazards in each brand was different due to some differences in the method of beers production in each company. The microbial hazards of beers were analyzed in different stages, including a) before pasteurization (Wort boiling and filtration stages), b) after pasteurization, and c) after the packaging process. Also, packaging materials were checked to identify sources and kinds of actual or potential contaminations (Figure 1).

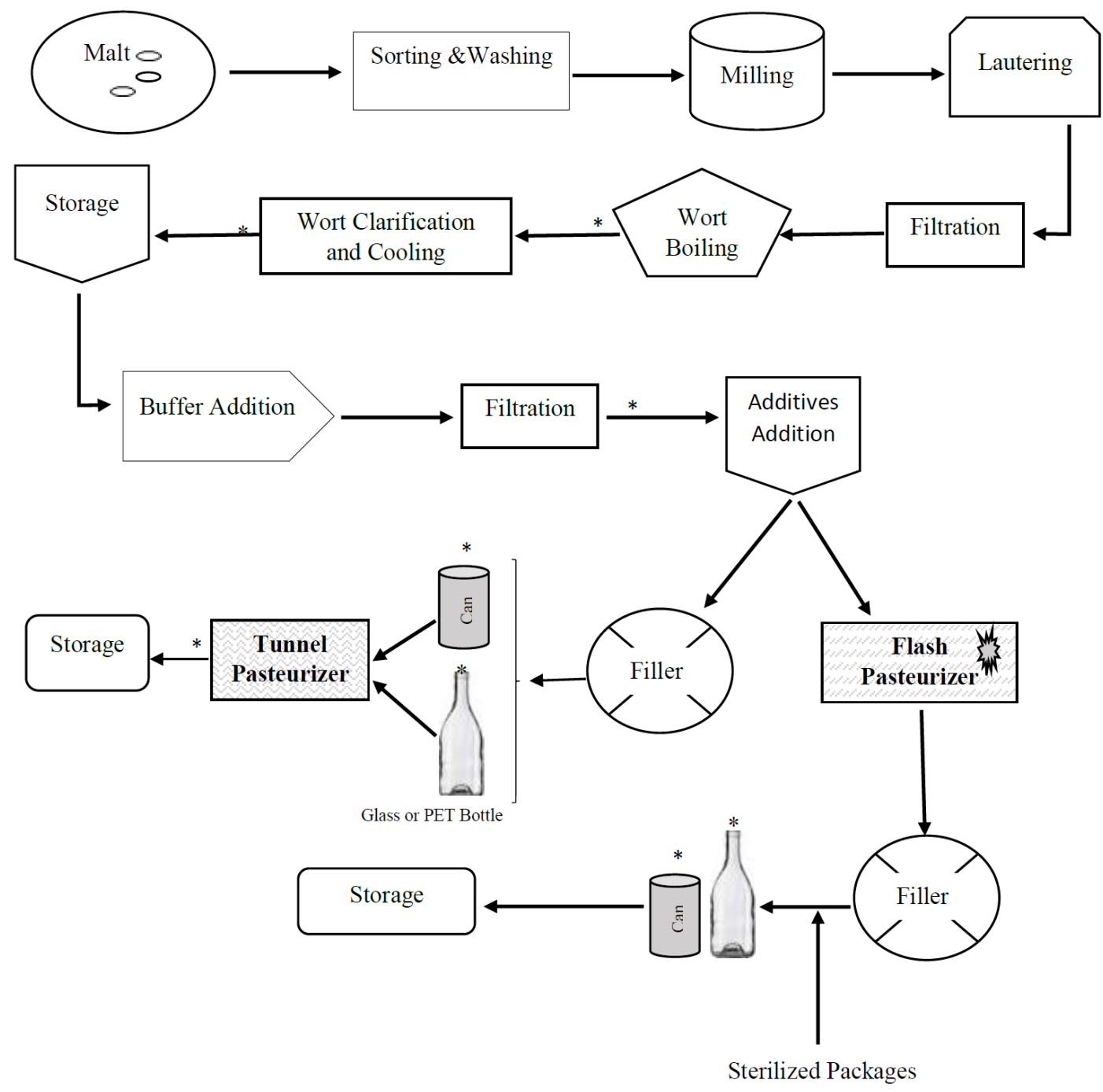

Figure 1. Non-alcoholic beer production line. Critical control points are indicated by *.

\subsection{Sample collection.}

One hundred milliliters of beer formulation of each brand from each step of the production line and final products (were packed in different packaging materials) were collected in sterile conditions. Samples were poured into sterile containers until analysis. 


\subsection{Enumeration of microorganisms.}

Yeasts, molds, and bacteria were enumerated according to the method described by Millet Lonvaud-Funel [20]. $1 \mathrm{ml}$ of each sample was diluted with peptone water based on the serial method. According to evaluate the effect of packaging material, $100 \mathrm{ml}$ of sterile peptone water was poured into each one of the empty containers of beers and was shaken. An aliquot in each container was evacuated into sterile Erlenmeyer flasks, and an appropriate serial dilution of each sample was prepared. An aliquot $2 \mathrm{ml}$ of diluted samples were cultured on different solid mediums. This method was applied for determining total viable microorganisms counts, molds, yeasts, and food molds and yeasts by culturing on different microbial mediums include plate count agar (PCA), yeast extract glucose (YEG), wort agar, and malt extract agar, respectively. All cultured plates were incubated at $37{ }^{\circ} \mathrm{C}$ for $48-96 \mathrm{~h}$ except for total viable

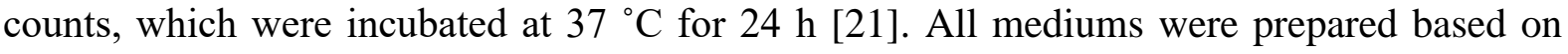
manufacturer instructions.

\subsection{DNA extraction from pure cultures.}

Four colonies of molds and yeasts with different morphology were isolated from malt extract agar. Two milliliters of each culture was centrifuged at $14000 \mathrm{~g}$ for $5 \mathrm{~min}$ at $4{ }^{\circ} \mathrm{C}$ for pelleting the cells, which were subjected to DNA extraction according to the method described by Cocolin et al. [22]. The pelleted cell was resuspended in $300 \mathrm{ml}$ of breaking buffer [2\% Triton X-100, $1 \%$ sodium dodecyl sulphate, $100 \mathrm{mM} \mathrm{NaCl}, 10 \mathrm{mM}$ Tris $(\mathrm{pH} 8)$, and $1 \mathrm{mM}$ EDTA (pH 8). Subsequently, $300 \mathrm{~mL}$ of phenol/chloroform/isoamyl alcohol (25: 24: 1, pH 6.7; Sigma) was added for extraction of DNA. The homogenized cells were centrifuged at $14000 \mathrm{~g}$ for $5 \mathrm{~min}$ at $41^{\circ} \mathrm{C}$, and the aqueous phase was then purified based on the kit manufacturer's suggestion.

\subsection{Polymerase chain reaction $(P C R)$.}

The extracted DNA was used as a template to perform the PCR process. All primers used in this study were targeted on the 16S rDNA and 26S rDNA gene (Table. 1). The DNAs extracted from cultures were amplified with the pairs of primers F27 and R1492. For the analysis of the diversity of fungal species, the proliferation of the gene, encoding 26S rDNA, was performed using PCR general primers includes NS1 / FR1. The amplification process was performed by PCR with a final volume of $25 \mu \mathrm{l}$, including $1 \mu \mathrm{l}$ of the sample, $2.5 \mu \mathrm{l}$ of PCR, 2 $\mu \mathrm{l}$ deoxynucleotide triphosphate ( $\mathrm{dNTP}$ ) mixture, $10 \mathrm{U}$ Taq polymerase enzyme, and $0.4 \mu \mathrm{M}$ of the primer. The reaction was performed in the Mastercycler. The PCR products were amplified on $8 \%$ polyacrylamide gel, directly. Polyacrylamide gel contained urea and formaldehyde to obtain a concentration gradient of 20-50\% for fungi. The denaturing gradient gel electrophoresis (DGGE) process was carried out for $30 \mathrm{~min}$ at $40 \mathrm{~V}$, and $15 \mathrm{~h}$ and $30 \mathrm{~min}$ at $60 \mathrm{~V}$, followed by ethidium bromide staining.

Table 1. Primers used in this study.

\begin{tabular}{|c|c|c|c|c|}
\hline Specificity & Primer name & Sequence $5^{\prime} \rightarrow 3^{\prime}$ & Annealing temperature (C) & Reference \\
\hline \multirow[t]{2}{*}{ Bacteria } & F27 & AGAGTTTGATCMTGGCTCAG & 56 & [23] \\
\hline & R1494 & CTACGGYTACCTTGTTACGAC & 56 & [24] \\
\hline Fungi & NS1/FR1 & $\begin{array}{l}\text { GTAGTCATATGCTTGTCTC } \\
\text { AIC CAT TCA ATC GGT AIT }\end{array}$ & $\begin{array}{c}49 \\
-\end{array}$ & [24] \\
\hline
\end{tabular}


Gel imaging was done with a digital camera. The desired bands were separated from the gel by a sterile blade and incubated at $4{ }^{\circ} \mathrm{C}$ in Tris-EDTA buffer $(\mathrm{pH}=8)$, which allowed separating DNA from the polyacrylamide gel. The resulting DNA is used directly for further amplification. Bands separated by the GC-Clamp primers were amplified as mentioned above and re-injected onto DGGE gel to confirm their identity and purity before sequencing. For sequencing, the isolated DNA was amplified by previous primer pairs without GC-Clamp as the method described in the previous steps.

\subsection{Sensitivity of method.}

The sensitivity of Real-time PCR assays was determined by amplifying decimal diluted, purified DNA of known concentration of each target species, individually or simultaneously. The experiment was run in triplicate for each dilution.

\subsection{Statistical analysis.}

All experiments were performed at least three replicates. Duncan Multiple Range Test was performed to determine the least significant difference (LSD) by SPSS 18.1 software. LSD was used to compare means of total counts, yeast, and mold counts in all beers samples.

\section{Results and Discussion}

\subsection{Enumeration of microorganisms.}

Microbial counts at different stages of non-alcoholic beer production in four different brands are shown in Tables 2 and 3.

Table 2. Viable microbial counts $(\log 10 \mathrm{CFU}$ ml-1) in beers at manufacturing control points of non-alcoholic

\begin{tabular}{|c|c|c|c|c|}
\hline \multirow[t]{2}{*}{ Control point } & \multicolumn{4}{|c|}{ 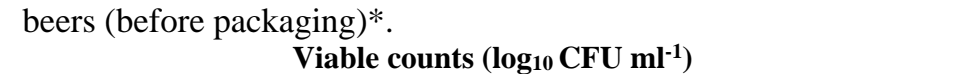 } \\
\hline & \multirow{2}{*}{ Brand A } & \multirow{2}{*}{$\begin{array}{l}\text { Viable counts } \\
\text { Brand B } \\
\end{array}$} & \multirow{2}{*}{ Brand C } & \multirow{2}{*}{ Brand D } \\
\hline After Wort boiling & & & & \\
\hline $\mathrm{T}$ & $-* *$ & $1.86 \pm 0.23^{\mathrm{Ab}}$ & - & nd \\
\hline $\mathrm{Y}+\mathrm{M}$ & - & $1.10 \pm 0.17^{\mathrm{Ac}}$ & - & nd \\
\hline $\mathrm{Y}$ & - & nd & - & nd \\
\hline $\mathrm{FY}+\mathrm{M}$ & - & nd & - & nd \\
\hline \multicolumn{5}{|l|}{ After clarification } \\
\hline $\mathrm{T}$ & - & $4.43 \pm 0.51^{\mathrm{Aa}}$ & - & $4.51 \pm 0.39^{\mathrm{Aa}}$ \\
\hline $\mathrm{Y}+\mathrm{M}$ & - & $1.20 \pm 0.17^{\mathrm{Ac}}$ & - & nd \\
\hline $\mathrm{Y}$ & - & nd & - & nd \\
\hline $\mathrm{FY}+\mathrm{M}$ & - & nd & - & nd \\
\hline \multicolumn{5}{|l|}{ After filtration } \\
\hline $\mathrm{T}$ & $3.96 \pm 0.30^{\mathrm{Aa}}$ & $4.10 \pm 0.17 \mathrm{Aab}$ & $\begin{array}{l}1.73 \pm \\
0.51^{\mathrm{Ba}}\end{array}$ & $\begin{array}{c}1.75 \pm \\
0.18^{\mathrm{BCb}} \\
\end{array}$ \\
\hline $\mathrm{Y}+\mathrm{M}$ & $\begin{array}{l}3.38 \pm \\
0.37^{\mathrm{Aab}} \\
\end{array}$ & $2.33 \pm 0.57^{\mathrm{Bb}}$ & $\begin{array}{l}1.40 \pm \\
0.34 \mathrm{Ca}\end{array}$ & nd \\
\hline $\mathrm{Y}$ & $2.77 \pm 0.15^{\mathrm{Ab}}$ & nd & nd & nd \\
\hline $\mathrm{FY}+\mathrm{M}$ & $2.02 \pm 0.26^{\mathrm{Ac}}$ & nd & nd & nd \\
\hline \multicolumn{5}{|c|}{ Unpacked beer after pasteurization } \\
\hline $\mathrm{T}$ & - & nd & nd & nd \\
\hline $\mathrm{Y}+\mathrm{M}$ & - & nd & nd & nd \\
\hline $\mathrm{Y}$ & - & nd & nd & nd \\
\hline $\mathrm{FY}+\mathrm{M}$ & - & nd & nd & nd \\
\hline
\end{tabular}


According to Tables 2 and 3, empty packaging materials and some beer samples before pasteurization contain low counts of microbial species; however, viable counts (total microbes or yeast or mold) were not detected in most of the brand's samples before the pasteurization stage. According to Table 3, none of the viable organisms were detected in all pasteurized samples. Bacterial contaminations (ranging from 5.64 to $10.22 \log 10 \mathrm{CFU} \mathrm{ml}^{-1}$ ) were observed in empty packaging materials of most of the brands (Table. 3). Packaging materials were cultured in YEG determined the presence of yeasts and molds (between the ranges of $1.74-$ $\left.4.39 \log 10 \mathrm{CFU} \mathrm{m} \mathrm{m}^{-1}\right)$.

Half of the packaging materials of all brands were contaminated with food yeasts. PET packaging materials of brands A and B were free from yeasts. The maximum yeast and mold colonies were obtained from glass packaging material of brand $B(p<0.05)$.

Table 3. Viable microbial counts $(\log 10 \mathrm{CFU}$ ml-1) in packed beers before or after pasteurization (after packaging)*.

\begin{tabular}{|c|c|c|c|c|}
\hline \multirow{3}{*}{$\begin{array}{l}\text { Control points } \\
\text { PET packed before pasteurization } \\
\end{array}$} & \multicolumn{4}{|c|}{ Viable counts $\left(\log _{10} \mathrm{CFU} \mathrm{ml^{-1 }}\right)$} \\
\hline & \multirow[t]{2}{*}{ Brand A } & \multirow[t]{2}{*}{ Brand B } & \multirow[t]{2}{*}{ Brand C } & \multirow[t]{2}{*}{ Brand D } \\
\hline & & & & \\
\hline $\mathrm{T}$ & $4.76 \pm 0.15^{\mathrm{cd}}$ & - & - & - \\
\hline $\mathrm{Y}+\mathrm{M}$ & $2.99 \pm 0.30^{\mathrm{e}}$ & - & - & - \\
\hline $\mathrm{Y}$ & $2.29 \pm 0.34^{\mathrm{e}}$ & - & - & - \\
\hline $\mathrm{FY}+\mathrm{M}$ & $2.65 \pm 0.75^{\mathrm{e}}$ & - & - & - \\
\hline \multicolumn{5}{|l|}{ PET packed after pasteurization } \\
\hline $\mathrm{T}$ & nd & nd & - & nd \\
\hline $\mathrm{Y}+\mathrm{M}$ & nd & nd & - & nd \\
\hline $\mathrm{Y}$ & nd & nd & - & nd \\
\hline $\mathrm{FY}+\mathrm{M}$ & nd & nd & - & nd \\
\hline \multicolumn{5}{|l|}{ Can packed after pasteurization } \\
\hline $\mathrm{T}$ & -** & nd & - & nd \\
\hline $\mathrm{Y}+\mathrm{M}$ & - & nd & - & nd \\
\hline $\mathrm{Y}$ & - & nd & - & nd \\
\hline $\mathrm{FY}+\mathrm{M}$ & - & nd & - & nd \\
\hline \multicolumn{5}{|l|}{ Glass bottled before pasteurization } \\
\hline $\mathrm{T}$ & $5.48 \pm 0.53^{\mathrm{c}}$ & - & - & - \\
\hline $\mathrm{Y}+\mathrm{M}$ & $4.02 \pm 0.56^{\mathrm{d}}$ & - & - & - \\
\hline $\mathrm{Y}$ & $4.33 \pm 0.34^{\mathrm{d}}$ & - & - & - \\
\hline $\mathrm{FY}+\mathrm{M}$ & $4.28 \pm 0.32^{\mathrm{d}}$ & - & - & - \\
\hline \multicolumn{5}{|l|}{ Glass bottled after pasteurization } \\
\hline $\mathrm{T}$ & nd & - & - & - \\
\hline $\mathrm{Y}+\mathrm{M}$ & nd & - & - & - \\
\hline $\mathrm{Y}$ & nd & - & - & - \\
\hline $\mathrm{FY}+\mathrm{M}$ & nd & - & - & - \\
\hline \multicolumn{5}{|l|}{ Empty PET container } \\
\hline $\mathrm{T}$ & $7.97 \pm 0.28^{\mathrm{Ab}}$ & $7.97 \pm 0.28^{\mathrm{Aa}}$ & - & $5.64 \pm 0.29^{\mathrm{Ba}}$ \\
\hline $\mathrm{Y}+\mathrm{M}$ & $1.74 \pm 0.18^{\mathrm{Af}}$ & $1.74 \pm 0.18^{\mathrm{Ad}}$ & - & $1.74 \pm 0.18^{\mathrm{Ac}}$ \\
\hline $\mathrm{Y}$ & nd & nd & - & $1.00 \pm 0.00^{\mathrm{A}}$ \\
\hline $\mathrm{FY}+\mathrm{M}$ & nd & nd & - & $1.4 \pm 0.34^{\mathrm{Ad}}$ \\
\hline \multicolumn{5}{|l|}{ Empty can container } \\
\hline $\mathrm{T}$ & - & $6.89 \pm 0.10 \mathrm{~A}^{\mathrm{b}}$ & $7.22 \pm 0.48^{\mathrm{Aa}}$ & $6.22 \pm 0.59^{\mathrm{Ba}}$ \\
\hline $\mathrm{Y}+\mathrm{M}$ & - & $\begin{array}{l}1.81 \pm \\
0.20 \mathrm{~A}^{\mathrm{Bd}} \\
\end{array}$ & $1.81 \pm 0.20 \mathrm{~A}^{\mathrm{Bb}}$ & $2.64 \pm 0.95^{\mathrm{Ab}}$ \\
\hline $\mathrm{Y}$ & - & $1.30 \pm 0.00^{\mathrm{Be}}$ & nd & $1.69 \pm 0.09^{\mathrm{Ac}}$ \\
\hline $\mathrm{FY}+\mathrm{M}$ & - & $1.85 \pm 0.00^{\mathrm{A}}$ & nd & $1.60 \pm 0.00^{\mathrm{Bd}}$ \\
\hline \multicolumn{5}{|l|}{ Empty glass bottle } \\
\hline $\mathrm{T}$ & $10.22 \pm 0.48^{\mathrm{Aa}}$ & $7.16 \pm 0.73^{\mathrm{Ba}}$ & - & - \\
\hline $\mathrm{Y}+\mathrm{M}$ & $1.81 \pm 0.20^{\mathrm{Bf}}$ & $4.39 \pm 1.39^{\mathrm{Ac}}$ & - & - \\
\hline $\mathrm{Y}$ & nd & $1.68 \pm 0.14^{\mathrm{Ad}}$ & - & - \\
\hline $\mathrm{FY}+\mathrm{M}$ & nd & $1.85 \pm 0.00^{\mathrm{Ad}}$ & - & - \\
\hline
\end{tabular}


Glass materials had the maximum total viable microorganisms count $(10.22 \log 10 \mathrm{CFU}$ $\mathrm{ml}^{-1}$ ) among all others. Microbial contamination of beer (total viable microorganisms and yeast and mold) were detected in brand B in most of the stages (after boiling, sedimentation, and clarifying) prior to pasteurization and packaging stages, while bacterial contaminations were the only contaminants in brand $\mathrm{D}$ beers (Table 2). Greater counts of bacteria were isolated from brands $\mathrm{B}$ and $\mathrm{D}$ (after the sedimentation process) followed by brands $\mathrm{A}$ and $\mathrm{C}$ (after the clarification stage). Before pasteurization, the least occurrence of bacteria was seen in brand D after the clarifying stage ( $\mathrm{p}$ 0.05). On the other hand, all kinks of evaluated microorganism (bacteria, yeast, and molds) were growing in brand A samples even after the clarifying stage. However, living organism species in brand $\mathrm{C}$ were similar to brand $\mathrm{B}$ (Table. 2). According to the experimental data, pasteurization had an impressive effect on the destruction of all kinds of living germs ( $\mathrm{p}<0.05)$. As clearly shown in Tables 1 and 2 , the presence of microorganisms was detected in all steps of beer processing before pasteurization.

Non-alcoholic beer is accepted by all Muslims and other religious people in Iran and is consumed as an alternative drink to alcoholic beverages in most ceremonies. Production of beer under unhygienic conditions enhances the risk of microbial contamination due to the presence of nutritious components in this product [15, 21, 25-27]. Different microorganisms are involved in the beer spoilage, including lactic acid bacteria (Lactobacilli and Pedicocci genesis), wild yeasts (Saccharomyces cerevisiae and Candida pelliculosa), and cereal mold (Fusarium) [28-30].

The overall results were shown in Tables 2 and 3, revealed the microbial contamination in the brewing line of four famous Iranian brands before the pasteurization step. Heat treatment of food products reduces the number of pathogenic microorganisms and enhances the storage quality of the product by suppressing molds, yeasts, and bacteria that cause infection [23]. Indeed, the pasteurization process is a specific stage for improving beer's microbial quality and can be considered as a CCP in brewing.

Beers produced by four manufacturers attained a temperature of about $65^{\circ} \mathrm{C}$ at the wort boiling stage. This temperature is not enough to kill all the viable cells and spores; however, it reduces the viable cells counts. The total counts of $1.86 \log 10 \mathrm{CFU} \mathrm{ml}{ }^{-1}$ recorded for brand $\mathrm{B}$ after the boiling step revealed the survival of some microorganisms, which could originate from malt seeds [26]. Moreover, an increase in the total viable counts after sedimentation of brands $\mathrm{B}$ and $\mathrm{D}$ indicated the participation of these microorganisms in the processing of beers. After clarifying the process, high counts of microorganism's species in brand A could be associated with the method of processing since this producer steeps malt for a long time in tanks before extraction. Steeping malt for a long time provides enough time for the proliferation of microbes. The isolation of yeasts and molds from brand $\mathrm{A}, \mathrm{B}$, and $\mathrm{C}$ is attributed to malt contamination [31-33]. However, low pH $(<5)$ of all non-alcoholic beers samples and the presence of natural antimicrobials may have contributed to low counts of microorganisms in all samples $[34,35]$. Fermented products are considered as safe products due to acidic nature, but an unhygienic process or low quality of raw materials cause microbial contaminations [35].

All samples were exposed to a similar temperature that was about $74{ }^{\circ} \mathrm{C}$. This temperature is an adequate temperature for eliminating most of the microorganisms, causing spoilage. On the other hand, the destruction of the microorganisms after pasteurization should not lead to neglecting to provide hygiene conditions in previous stages. Factors such as contaminated surfaces and equipment, sources of water, and infected malt are the contamination sources of such drinks before the pasteurization process [26]. 
Isolation of yeasts and molds from samples may be contributed to malt seeds, air, improper packaging materials, and poor environmental hygiene [21]. Molds and yeasts grew at a wide range of $\mathrm{pH}$ and temperature, and cause developing off-flavor and undesired taste and color. In addition, fungus family organisms are able to produce mycotoxins, which is a harmful component for human health $[14,36]$.

The major hazards in the processing of non-alcoholic beers are the presence of fermentative bacteria, yeasts, and molds, which could grow before pasteurization and develop undesirable products that influence final product quality. So, it is required to inform the beer producers about hazards and CCPs of non-alcoholic beers processing. Such control involves monitoring raw materials and water contamination, washing raw materials before the steeping stage, performing cleaning in place (CIP) practice before and after processing, using hygiene water for malt washing, steeping, and also for beers formulation diluting and following all sanitary rules in the processing line.

\subsection{Identification of organisms.}

In the present study, all of them specifically designed primers were amplified with nonspecific DNA. According to PCR results, different strains of Saccharomyces cerevisiae were present in beers contributed to brand A and B before pasteurization (Table 4). Moreover, Beers which produced by brand C contained Saccharomyces cerevisiae and Alternaria tenuissima. The results also determined the presence of Cladosporium cladosporioides, Candidia daunpuri, in the beer samples of brand $\mathrm{C}$ in the different stages of critical processing points. As shown in table 4, the presence of Pichia, Rhodotorula, Hansenia, and Wickerhamomyces anomalus was confirmed by PCR (Table 4). Wickerhamomyces anomalus is one of the candidian spoilage, which contributes to the contamination of food products with soil, contaminated fruits, and warm-blooded animals [38, 39].

Table 4. Representative yeast species in beer samples were detected by a polymerase chain reaction.

\begin{tabular}{|c|c|c|c|c|c|}
\hline Brand & Identification & Access code & $\begin{array}{c}\text { Sequence } \\
\text { size }\end{array}$ & $\begin{array}{c}\text { Homology } \\
(\%)\end{array}$ & Stage of sampling \\
\hline \multirow[t]{4}{*}{ A } & Saccharomyces cerevisiae 01 & KC1837221 & 826 & 88 & $\begin{array}{l}\text { PET Packed beer } \\
\text { before pasteurization }\end{array}$ \\
\hline & Saccharomyces cerevisiae T6 & GU320706.1 & 807 & 84 & $\begin{array}{l}\text { Glass bottled beer } \\
\text { before pasteurization }\end{array}$ \\
\hline & $\begin{array}{l}\text { Saccharomyces cerevisiae } \\
\text { YPDM1 }\end{array}$ & KY816912.1 & 841 & 99 & Before filtration \\
\hline & Saccharomyces cerevisiae TY-1 & KJ781352.1 & 1705 & 90 & After filtration \\
\hline \multirow[t]{2}{*}{ B } & $\begin{array}{l}\text { Saccharomyces cerevisiae } \\
\text { JYC2577 }\end{array}$ & KJ781352.1 & 349 & 75 & After filtration \\
\hline & Saccharomyces cerevisiae $\mathrm{RC} 231$ & KY102043.1 & 710 & 93 & After filtration \\
\hline \multirow[t]{8}{*}{$\mathrm{C}$} & Saccharomyces cerevisiae TY-1 & KJ781352.1 & 1705 & 90 & Before filtration \\
\hline & Pichia codori lozoyuela $13 \mathrm{Y}$ & MF685423.1 & 118 & 100 & Before filtration \\
\hline & Rhodotorula dairenensis & LC390315.1 & 556 & 99 & Before filtration \\
\hline & Alternaria tenuissima ZTFb9 & MH790321.1.1 & 515 & 100 & After filtration \\
\hline & Hansenia & $\mathrm{AJ} 271032$ & 284 & 99 & After filtration \\
\hline & Wickerhamomyces anomalus & KY605149.1 & 542 & 84 & After filtration \\
\hline & $\begin{array}{l}\text { Cladosporium cladosporioides } \\
\text { BEOFB } 1827 \mathrm{~m}\end{array}$ & MH647077.1 & 498 & 100 & Before packaging \\
\hline & Candidia daunpuri & KY102043.1 & 409 & 99 & Before packaging \\
\hline
\end{tabular}

It is difficult to identify and determine beer spoilage microorganisms since the number of viable germs in beer is very limited. Nowadays, new methods such as PCR, immunoassay, fluorescence, and luminescence tests are used as accurate methods for identifying microorganisms instead of traditional methods (i.e., culturing in nutritious media) [40]. In 
recent research, for precise identification of contaminating organisms in beers, the PCR protocols were applied to use the minimum time for denaturation, annealing, and extension. The PCR technique gives precise results more rapidly than other conventional methods. This technique ensures financial benefits for the beers manufacturer. Overall, the PCR assay applied for microbial control of the finished products should be rapid, sensitive, and simple. Simplicity helps to avoid cross-contamination of sample treatments.

Results of molecular identification of microorganisms isolated from beers of different brands determined that saccharomyces yeast was the major microorganisms identified in all brands. Spoilage of non-alcoholic beers is due to the presence of two yeast groups includes Saccharomyces, which is predominantly Saccharomyces cerevisiae, and non-saccharomyces yeast (Brettanomyces, Candidia, Debaryomyces, Hanseniaspora, Kluyveromyces, Pichia, Torulaspora, and Zygosaccharomyces) [7]. According to results obtained by the PCR method, both of the mentioned groups of yeasts caused beers spoilage. Furthermore, isolation of Alternaria tenuissima and Cladosporium cladosporioides from brand $\mathrm{C}$ samples could be originated from contaminated malt. This spoilage may cause undesired aroma and off-flavor like soil taste. Moreover, production of mycotoxins is another concern that may be produced as secondary metabolites of molds during growth and have adverse effects on the food product quality; however, the most dangerous mycotoxins are produced by the Fusarium, Aspergillus, and Penicillium molds. Nevertheless, as determined in the previous section, the pasteurization process could destroy any kinds of viable organisms in beers such that no microbial contamination was detected in pasteurized products of all four brands. Overall, also complying with the sanitary condition during processing, which preventing production moldy off-taste and off-flavor, is an essential way.

\section{Conclusions}

In the recent study, the microbiological quality of non-alcoholic beer manufacturing of four brands (A-D) was determined by traditional and modern methods. This study demonstrated that PCR is a promising method in detecting specific organisms in less than 10 h. PCR method distinguished all of the contaminants before pasteurization in non-alcoholic beer, including Saccharomyces, Pichia, Rhodotorula, Alternaria, Hansenia, Wickerhamomyces, and Cladosporium, which might originate from contaminated raw material or unhygienic conditions processing. According to experimental results, the pasteurization process destroyed all of the viable microorganisms in the non-alcoholic beer. The major CCPs in non-alcoholic processing are wort boiling, clarification, filtration, packaging, and pasteurization stages that could be controlled by producers; indeed, maintenance of proper sanitation, using good quality raw materials, and applying pasteurization process will improve the microbial quality of non-alcoholic beer.

\section{Funding}

This research received no external funding.

\section{Acknowledgments}

The authors are thankful to the Halal Research Centre of the Islamic Republic of Iran for providing facilities for the completion of this research work. 


\section{Conflicts of Interest}

\section{Authors have no conflict of interest to declare.}

\section{References}

1. Brányik, T.; Silva, D.P.; Baszczyňski, M.; Lehnert, R.; Silva, J.B A. A review of methods of low alcohol and alcohol-free beer production. Journal of Food Engineering 2012, 108, 493-506, https://doi.org/10.1016/j.jfoodeng.2011.09.020.

2. Zendeboodi, F.; Jannat, B.; Sohrabvandi, S.; Khanniri, E.; Mortazavian, A.M.; Khosravi, K.; Sarmadi, B.; Asadzadeh, S.; Amirabadi, P.E.; Esmaeili, S. Monitoring of ethanol content in non-alcoholic beer stored in different packages under different storage temperatures. Biointerface Research in Applied Chemistry 2019, 9 (6), 4624-4628.

3. Bellut, K.; Michel, M.; Zarnkow, M.; Hutzler, M.; Jacob, F.; Atzler, J.J.; Hoehnel, A.; Lynch, K.M.; Arendt, E.K.Screening and Application of Cyberlindnera Yeasts to Produce a Fruity, Non-Alcoholic Beer. Fermentation 2019.5(4), 103.

4. Sohrabvandi, S.; Mousavi, S.M.; Razavi, S.H.; Mortazavian, A.M.; Rezaei, K. Alcohol-free beer: Methods of production, sensorial defects, and healthful effects. Food Reviews International 2010, 26, 335-352.

5. Sohrabvandi, S.; Razavi, S.H.; Mousavi, S.M.; Mortazavian, A.M. Viability of probiotic bacteria in low alcohol-and non-alcoholic beer during refrigerated storage. Philipp Agric Sci 2010, 93, 24-28.

6. Krebs, G.; Müller, M.; Becker, T.; Gastl, M. Characterization of the macromolecular and sensory profile of non-alcoholic beers produced with various methods. Food Research International 2019, 116, 508-517.

7. Sohrabvandi, S.; Razavi, S.H.; Mousavi, S.M.; Mortazavian, A.; Rezaei, K. Application of Saccharomyces rouxii for the production of non-alcoholic beer. Food Science and Biotechnology 2009, 18, 1132-1137.

8. Hiko, A; Yimer M. Levels of microbial contamination in non-alcoholic beverages from selected eastern Ethiopian towns markets. Scientific African, 2020, e00223.

9. Jaskula-Goiris, B.; De Causmaecker, B.; De Rouck, G.; Aerts, G.; Paternoster, A.; Braet, J.; De Cooman, L. Influence of transport and storage conditions on beer quality and flavour stability. Journal of the Institute of Brewing 2019, 125, 60-68, https://doi.org/10.1002/jib.535.

10. Greifenstein, M.; White, D.W.; Stubner, A.; Hout, J.;Whelton, A.J. Impact of temperature and storage duration on the chemical and odor quality of military packaged water in polyethylene terephthalate bottles. Science of The Total Environment 2013, 456-457, 376-383, https://doi.org/10.1016/j.scitotenv.2013.03.092.

11. Pickering, G.J. Low-and reduced-alcohol wine: a review. Journal of wine research 2000, 11, 129-144, https://doi.org/10.1080/09571260020001575.

12. Bellut, K.; Michel, M.; Zarnkow, M.; Hutzler, M.; Jacob, F.; Atzler, J.J.; Hoehnel, A.; Lynch, K.M.; Arendt, E.K. Screening and Application of Cyberlindnera Yeasts to Produce a Fruity, Non-Alcoholic Beer. Fermentation 2019, 5(4), 103.

13. Flouros, A.; Apostolopoulou, A.; Demertzis, P.;Akrida-Demertzi, K. Note: Influence of the packaging material on the major volatile compounds of tsipouro, a traditional Greek distillate. Food science and technology international 2003, 9, 371-378, https://doi.org/10.1177/1082013203038872.

14. Bryan, F.L. Risks of practices, procedures and processes that lead to outbreaks of foodborne diseases. Journal of food protection 1988, 51, 663-673, https://doi.org/10.4315/0362-028X-51.8.663.

15. Khaniki, G.R.J.; Mahdavi, M.; Mohebbi, M.R. HACCP application for treatment of drinking water for Germi in Iran. Journal of food, agriculture \& environment 2009, 7, 709-712.

16. Dzwolak, W. Assessment of HACCP plans in standardized food safety management systems-the case of small-sized Polish food businesses. Food Control 2019 106, 106716.

17. Pham, T.; Wimalasena, T.; Box, W.G.; Koivuranta, K.; Storgårds, E.; Smart, K A.; Gibson, B. R. Evaluation of ITS PCR and RFLP for Differentiation and Identification of Brewing Yeast and Brewery 'Wild' Yeast Contaminants. Journal of the Institute of Brewing 2011, 117, 556-568.

18. Rahman, H.U.; Yue, X.; Yu, Q.; Zhang, W.; Zhang, Q.; Li, P. Current PCR-based methods for the detection of mycotoxigenic fungi in complex food and feed matrices. World Mycotoxin Journal 2020, 13(2), 139-150.

19. Satokari, R.; Juvonen, R.; Mallison, K.; von Wright, A.; Haikara, A. Detection of beer spoilage bacteria Megasphaera and Pectinatus by polymerase chain reaction and colorimetric microplate hybridization. International Journal of Food Microbiology 1998, 45, 119-127, https://doi.org/10.1016/S01681605(98)00154-8.

20. Millet, V.; Lonvaud-Funel, A. The viable but non-culturable state of wine microorganisms during storage. Letters in Applied Microbiology 2000, 30, 136-141, https://doi.org/10.1046/j.1472-765x.2000.00684.x.

21. Oranusi, S.; Umoh, V.; Kwaga, J. Hazards and critical control points of kunun-zaki, a non-alcoholic beverage in Northern Nigeria. Food microbiology 2003, 20, 127-132, https://doi.org/10.1016/S0740-0020(02)000722.

22. Cocolin, L.; Bisson, L.; Mills, D. Direct profiling of the yeast dynamics in wine fermentations. FEMS microbiology letters 2000, 189, 81-87, https://doi.org/10.1111/j.1574-6968.2000.tb09210.x. 
23. Gomes, N.; Heuer, H.; Schönfeld, J.; Costa, R.; Mendonca-Hagler, L.; Smalla, K. Bacterial diversity of the rhizosphere of maize (Zea mays) grown in tropical soil studied by temperature gradient gel electrophoresis. Plant and soil 2001, 232, 167-180, https://doi.org/10.1023/A:1010350406708.

24. Hoshino, Y.T.; Morimoto, S. Comparison of $18 \mathrm{~S}$ rDNA primers for estimating fungal diversity in agricultural soils using polymerase chain reaction-denaturing gradient gel electrophoresis. Soil science and plant nutrition 2008, 54, 701-710, https://doi.org/10.1111/j.1747-0765.2008.00289.x.

25. Ehiri, J.E.; Azubuike, M.C.; Ubbaonu, C.N.; Anyanwu, E.C.; Ibe, K.M.; Ogbonna, M.O. Critical control points of complementary food preparation and handling in eastern Nigeria. Bulletin of the World Health Organization 2001, 79, 423-433.

26. Umaru, G.A.; Tukur, I.S.; Akensire, U.A.; Adamu, Z.; Bello, O.A.; Shawulu, A.H.; Audu, M.; Sunkani, J.; Adamu, S.; Adamu, N. Microflora of Kunun-Zaki and Sobo drinks in relation to public health in Jalingo Metropolis, North-Eastern Nigeria. International journal of food research 2014, 1, 16-21.

27. Abbet, M. Understanding the emerging beer spoilage yeast Saccharomyces cerevisiae var. diastaticus. 2020.

28. Anli, E.; Alkis, İ.M. Ochratoxin A and brewing technology: a review. Journal of the Institute of Brewing 2010, 116, 23-32, https://doi.org/10.1002/j.2050-0416.2010.tb00394.x.

29. Sakamoto, K.; Konings, W.N. Beer spoilage bacteria and hop resistance. International journal of food microbiology 2003, 89, 105-124, https://doi.org/10.1016/S0168-1605(03)00153-3.

30. Storåards, E.; Suiiiko, M.L.; Pot, B.; Vanhonacker, K.; Janssins, D.; Broomfield, P.; Banks, J. Detection and identification of Lactobacillus lindneri from brewery environments. Journal of the Institute of Brewing 1998, 104, 46-54, https://doi.org/10.1002/j.2050-0416.1998.tb00974.x.

31. Inabo, H.; Ogbadu, L.; Umoh, V.; Ameh, J. Microbiological quality of selected marketed condiments. Namoda Techscope J 2000, 4, 20-30.

32. Obuekwe, C.; Ogbimi, A. Prevalence of Bacillus cereus and some other gram-positive bacteria in Nigerian dried food condiments. Nigeria food J 1989, 7, 1-19.

33. Mastanjević, K.; Lukinac, J.; Jukić, M.; Šarkanj, B.; Krstanović, V.; Mastanjević, K. Multi-(myco) toxins in malting and brewing by-products. Toxins 2019, 11(1), 30.

34. Sohrabvandi, S.; Mortazavian, A.; Rezaei, K. Advanced analytical methods for the analysis of chemical and microbiological properties of beer. Journal of food and drug analysis 2011, 19, 202-222, https://doi.org/10.38212/2224-6614.2228.

35. Sohrabvandi, S.; Mortazavian, A.; Rezaei, K. Health-related aspects of beer: a review. International Journal of Food Properties 2012, 15, 350-373, https://doi.org/10.1080/10942912.2010.487627.

36. Van Iersel, M.; Brouwer-Post, E.; Rombouts, F.; Abee, T. Influence of yeast immobilization on fermentation and aldehyde reduction during the production of alcohol-free beer. Enzyme and microbial technology 2000 , 26, 602-607, https://doi.org/10.1016/S0141-0229(00)00140-X.

37. Swanson, K.M. Microorganisms in Foods: Use of Data for Assessing Process Control and Product Acceptance. Springer Science, 2011.

38. Satora, P.; Tarko, T.; Sroka, P.; Blaszczyk, U. The influence of Wickerhamomyces anomalus killer yeast on the fermentation and chemical composition of apple wines. FEMS yeast research 2014, 14, 729-740, https://doi.org/10.1111/1567-1364.12159.

39. Solairaj, D.; Legrand, N.N.G.; Yang, Q.; Zhang, H.Isolation of pathogenic fungi causing postharvest decay in table grapes and in vivo biocontrol activity of selected yeasts against them. Physiological and Molecular Plant Pathology, 2020, 101478.

40. Jespersen, L.; Jakobsen, M. Specific spoilage organisms in breweries and laboratory media for their detection. International journal of food microbiology 1996, 33, 139-155, https://doi.org/10.1016/01681605(96)01154-3. 